\title{
Effect of Living Mulch on Soil Conditions and Morphometrical Indices of Sweet Cherry Trees
}

\author{
Tatyana Gerasko ${ }^{1,}$,, Svitlana Pyda ${ }^{2}$, Iryna Ivanova ${ }^{1}$ \\ ${ }^{1}$ Department of Horticulture, Viticulture and Biochemistry, Faculty of Agricultural Technologies and Ecology, Dmytro Motornyi Tavria State \\ Agrotechnological University, Melitopol, Ukraine \\ ${ }^{2}$ Department of Botany and Zoology, Faculty of Chemical Biology, Volodymyr Hnatyuk Ternopil National Pedagogical University, Ternopil, \\ Ukraine
}

Email address:

tetiana.herasko@tsatu.edu.ua (T. Gerasko), spyda@ukr.net (S. Pyda), irynaivanova2017@gmail.com (I. Ivanova)

${ }^{*}$ Corresponding author

\section{To cite this article:}

Tatyana Gerasko, Svitlana Pyda, Iryna Ivanova. Effect of Living Mulch on Soil Conditions and Morphometrical Indices of Sweet Cherry Trees. International Journal of Applied Agricultural Sciences. Vol. 7, No. 1, 2021, pp. 50-56. doi: 10.11648/j.ijaas.20210701.14

Received: January 14, 2021; Accepted: January 22, 2021; Published: January 28, 2021

\begin{abstract}
In order to maintain natural biocenosis and to create optimal conditions for reproducing soil fertility, it is necessary to keep the soil under living mulch in organic orchards. But the effect of the living mulch on soil properties and biometric indices of trees has not yet been fully investigated. This work aimed at examining the effects of living mulch (compared with standard mechanical cultivation) on soil moisture, soil temperature and biometric indices of sweet cherry trees in the arid conditions of the Southern Steppe of Ukraine. The work was conducted from 2014 to 2019 in the Southern Steppe of Ukraine in Zelene village near the city of Melitopol (46 $\left.46^{\prime} \mathrm{N}, 35^{\circ} 17^{\prime} \mathrm{E}\right)$. In organic sweet cherry (Prunus avium L./Prunus mahaleb) orchard standard mechanical cultivation (MC) was compared with living mulch - spontaneous vegetation cover (LM). The soil moisture at $20 \mathrm{~cm}$ depth was significantly greater under LM (an average of 3,9\%), the soil temperatures under LM plots were lower (an average of $1.5^{\circ} \mathrm{C}$ over 6 years of research), in comparison to MC. It was established that the trunk cross sectional area of sweet cherry trees was significantly reduced under LM - by 1.2-2.1 times. However, LM contributed to an increase in the shoot growth efficiency by 1.5-2.9 times, compared to MC. The ratio of total leaf area to the trunk cross sectional area was also significantly greater in conditions of LM, since 2015 by 1.3-2.5 times. The weather conditions of the year significantly influenced the formation of the biometric indices of the trees - Year $\times$ orchard floor management system interactions were significantly throughout all years of research. Investigated sweet cherry cultivars (Valery Chkalov and Dilemma) respondend to the floor management systems in a similar way - their biometric indices did not differ significantly.
\end{abstract}

Keywords: Prunus avium L., Prunus mahaleb, Organic Orchard, Biometric Indices, Soil Moisture, Soil Temperature

\section{Introduction}

Conscious attitude to life, awareness of environmental problems, encourage farmers to switch to organic technologies. But the issue of optimal orchard floor management system in an organic orchard has not been sufficiently studied, especially in the arid conditions of the Southern Steppe of Ukraine. In recent years, there is an increasing interest for use of living mulches in orchards.

Natural herbs can serveas a living mulch, improving the water regime, the physical condition of the soil $[1,2]$ and protecting it from erosion [3-5]; herbs have their own rhizosphere, which enriches the soil with organic matter [6-8], supplies plants with nitrogen (through symbiotic and associative bacteria) [9-11], phosphorus (through bacteria-phosphatesolubilizers) [12, 13]; flowering grasses attract pollinating insects $[14,15]$ and provide nutrition to beneficial insects $[16,17]$; volatile compounds that produce herbs (especially medicinal plants) can disorient pests and have a fungicidal effect [18].

It was reported that living mulches influence soil properties and tree performance in an organic apple orchard in northern Patagonia and disking is not a recommended practice because it may decrease the concentration of soil organic matter and leads to poor tree vigor that corresponds to low fruit bearing 
potential [19]. However, living mulches may reduce yield and tree size [5]. There are also reports that tree productivity does not depend on the orchard floor management system in an organic orchard [20-22]; or the treatment effect ceased to be significant, once the trees reached full production [23].

Thus, in order to maintain natural biocenosis and to create optimal conditions for reproducing soil fertility, it is necessary to keep the soil under living mulch in organic orchards. But the effect of the living mulch on biometric indices of trees has not yet been fully investigated. Little is known about the effects of living mulches on soil properties in organic sweet cherry orchards.

This work aimed at examining the effects of living mulch (compared with standard mechanical cultivation) on soil moisture, soil temperature and biometric indices of sweet cherry trees in the arid conditions of the Southern Steppe of Ukraine.

\section{Materials and Methods}

The work was conducted from 2014 to 2019 in the Southern Steppe of Ukraine in Zelene village near the city of Melitopol $\left(46^{\circ} 46^{\prime} \mathrm{N}, 35^{\circ} 17^{\prime} \mathrm{E}\right)$. The soil cover of the investigated area is the chestnut soils, which are very low-humus. Soils have a weakly alkaline reaction of soil solution $(\mathrm{pH}$ varies within 7.1-7.4). On the background of a light granulometric composition, the humus content in the upper humus horizon is $0.6 \%$. The analysis of aqueous extraction revealed that the total content of water-soluble salts does not exceed $0.015-0.024 \%$.

The long-term mean air temperature is $+10.6^{\circ} \mathrm{C}$. The summer months (June, July and August) have an average daily air temperature of $21-23^{\circ} \mathrm{C}$. Winters are warm with frequent thaws. The coldest months are January and February. During these months mean annual air temperature ranges minus $3.7-4.3^{\circ} \mathrm{C}$, but the minimum temperature is reduced to minus $26^{\circ} \mathrm{C}$. Mean annual precipitation for the last 10 years was approximately $481 \mathrm{~mm}$.

The analys of weather conditions over the years of the studies (Table 1) show that climate is warming - the average annual temperature was $0.8-1.6^{\circ} \mathrm{C}$ warmer relative to long-term normals. Winter conditions were more favorable, which can be seen in the coldest month - January (the air temperature was $0.3-1.6^{\circ} \mathrm{C}$ higher than long-term normals, with the exception of January 2016 and 2017).

Table 1. Weather conditions during 2014-19 relative to long-term normals as measured at the Melitopol weather station.

\begin{tabular}{|c|c|c|c|c|c|c|c|c|c|c|c|c|c|}
\hline \multicolumn{14}{|c|}{ Mean monthly temp $\left({ }^{\circ} \mathrm{C}\right)$} \\
\hline Yr & Jan. & Feb. & Mar. & Apr. & May & June & July & Aug. & Sept. & Oct. & Now. & Dec. & Average annual \\
\hline 2014 & +0.3 & +1.5 & +3.5 & +0.8 & +1.9 & -0.5 & +1.3 & +1.6 & +1.3 & -0.9 & -1.3 & +0.2 & +0.8 \\
\hline 2015 & +0.9 & +2.4 & +2.3 & -0.9 & +0.3 & +0.7 & 0 & +2.0 & +4.4 & -1.3 & +2.7 & +2.3 & +1.3 \\
\hline 2016 & -1.1 & +5.2 & +3.0 & +2.5 & -0.3 & +1.4 & +1.1 & +2.6 & +0.1 & -1.9 & -0.2 & -2.0 & +0.8 \\
\hline 2017 & -0.9 & +0.5 & +3.7 & -1.5 & -0.4 & +0.9 & -0.1 & +3.2 & +2.9 & +0.3 & +1.2 & +5.3 & +1.2 \\
\hline 2018 & +1.2 & +1.1 & -1.5 & +3.0 & +3.0 & +2.2 & +1.1 & +2.6 & +1.5 & +2.9 & -1.1 & +0.6 & +1.3 \\
\hline 2019 & +1.6 & +2.4 & +0.7 & +1.0 & +1.5 & +4.1 & -0.6 & +0.4 & +0.7 & +1.4 & +2.3 & +3.8 & +1.6 \\
\hline 2014 & +27 & -79 & -71 & +41 & +40 & +89 & -39 & -51 & +164 & -52 & -50 & +64 & +13 \\
\hline 2015 & -4 & -7 & +126 & +87 & -48 & +15 & +18 & -97 & -98 & -46 & +88 & -72 & -4 \\
\hline 2016 & +36 & +22 & -28 & -11 & +82 & -48 & -22 & -49 & +55 & -22 & +2 & -39 & -1 \\
\hline 2017 & +4 & -16 & -63 & +76 & -73 & -23 & +36 & +22 & +30 & +4 & -52 & -57 & -11 \\
\hline 2018 & +21 & +39 & +96 & -84 & -52 & -40 & +81 & -82 & +104 & -44 & -3 & +74 & +10 \\
\hline 2019 & +19 & -68 & +6 & +44 & +107 & -73 & -5 & +61 & -67 & -42 & -48 & -26 & -8 \\
\hline
\end{tabular}

Table 2. Hydrothermal coefficient (HTC).

\begin{tabular}{llllllll}
\hline Yr & Apr. & May & June & July & Aug. & Sept. & Oct. \\
\hline 2014 & 1.4 & 1.2 & 1.6 & 0.4 & 0.2 & 1.9 & $\mathrm{~nm}$ \\
2015 & $\mathrm{~nm}$ & 0.5 & 0.9 & 0.7 & 0 & 0 & $\mathrm{~nm}$ \\
2016 & 0.8 & 1.7 & 0.4 & 0.5 & 0.2 & 1.2 & $\mathrm{~nm}$ \\
2017 & $\mathrm{~nm}$ & 0.3 & 0.6 & 0.8 & 0.5 & 0.8 & 1.0 \\
2018 & 0.1 & 0.4 & 0.5 & 1.1 & 0.1 & 1.4 & 0.5 \\
2019 & 1.4 & 1.8 & 0.2 & 0.6 & 0.8 & 0.2 & 0.5 \\
Long-term normals & 1.1 & 0.9 & 0.9 & 0.6 & 0.5 & 0.8 & 1.0 \\
\hline
\end{tabular}

nm denote 'not measured': hydrothermal coefficient is not determined if the average monthly air temperature is less than $10^{\circ} \mathrm{C}$.

The average annual precipitation was not significantly different from long-term normals, but rainfall was distributed unevenly each year - occurring as wetting (mainly in January and September, with the exception of September 2015 and 2019) and drought (mainly in June and August). This is clearly seen in Table 2. For the estimation of the meteorological conditions we used Hydrothermal coefficient (HTC), which established as the ratio of the sum of precipitation (mm) during the period with average daily air temperatures above $10^{\circ} \mathrm{C}$ to the sum of temperatures at the same time, reduced by 10 times [24]. HTC characterizes not only the profitable part of the water balance (precipitation), but also the unproductive consumption of moisture (evaporation from the soil surface, vegetation). The criteria that characterize the intensity of droughts by the HTC are established: HTC $<0.5$ - sharp lack of precipitation, severe drought; $\mathrm{HTC}=0.6-0.7$ - insufficient moisture (very dry); HTC $=0.8-0.9$ - arid (non-severe drought); $\mathrm{HTC}=1.0-1,2$ - insufficient humidity; 1,3-1,6 - moderate humidity; HTC $>1.7$ - excess humidity [25].

Drought is a common occurrence in the Southern Steppe of Ukraine, especially in summer months. It was abnormally arid in August and September 2015, when only 0.9 and $0.5 \mathrm{~mm}$ precipitation. The hottest month of August was very dry during all years of research, except in 2019, when $56 \mathrm{~mm}$ of precipitation fell and the hydrothermal coefficient was higher than the long-term norm. 
The experiment was conducted in an organic sweet cherry orchard of Valery Chkalov and Dilemma cultivars (Prunus avium L.)/Prunus mahaleb) planted in 2011 at $7 \times 5 \mathrm{~m}$. Orchard rows were oriented north to south. Trees were trained as central leader.

The experiment was designed as a randomized complete block with two treatments, in triplicate. Each experimental plot consisted of 36 trees, spanning 3 rows with 12 trees per row. The 10 central trees of the middle row were used for measurements, and the other 26 were guard trees. Each experimental plot for soil analysis had an area of $210 \mathrm{~m}^{2}$ $(7 \mathrm{~m} \times 30 \mathrm{~m})$.

Since 2013 the experimental orchard has been maintained with two different orchard floor management systems (OFMS): standard mechanical cultivation - one discing at a 15 $\mathrm{cm}$ depth + manual weeding during the growing season (MC) was compared with living mulch - spontaneous vegetation cover (LM). The natural vegetation of grasses was mowed 4 times during the growing season and the clippings were left on the ground for decomposition. Any other management was identical in each treatment. Synthetic fertilizers and chemical plant protection products were not used.

Soil conditions were measured annually at the first decade of August. The soil was sampled to a depth of $20 \mathrm{~cm}$ at 5 randomly established locations in each plot. The soil water content was determined gravimetrically by oven drying $\left(105^{\circ} \mathrm{C}\right)$ until constant weight. Soil temperature at $20 \mathrm{~cm}$ depth was determined using a digital thermometer with a probe $125 \mathrm{~mm}$ long (Range: $-20^{\circ}$ to $200^{\circ} \mathrm{C}$ ).
Biometric indices of sweet cherry trees were determined according to generally accepted methods [26]: total annual vegetative growth was evaluated as product of number and length of new shoots per tree; trunk diameter at $0.3 \mathrm{~m}$ above the graft union was measured annually at mid-October and used to calculate trunk cross sectional area (TCSA). Shoot growth efficiency (SGE) was calculated as the ratio of total annual vegetative growth to the trunk cross sectional area. Leaf surface area was determined gravimetrically and used to calculate the total leaf area (TLA) given the number of leaves on the tree. Leaves for analysis were collected at the first decade of August, with the full development of the leaf surface. Leaf samples were collected from mid-shoot on the new growth found in the middle of the tree. Leaf efficiency (LE) was calculated as the ratio of TLA to the trunk cross sectional area.

Treatment means were compared using Minitab 19 software (Minitab Inc., State College, PA). Statistical analyses were undertaken using the general linear model and two-way normal ANOM procedure. A treatment effect significant at $P \leq$ 0.05 was further analyzed with the Tukey mean separation test at a significance level of $P \leq 0.05$.

\section{Results and Discussion}

Our studies showed a positive effect of LM on the Soil temperature and soil water content (Table 3). The soil temperatures under LM plots were lower, compared with the soil temperatures under MC plots.

Table 3. Effect of year $\times$ OFMS interactionon on soil conditions.

\begin{tabular}{|c|c|c|c|c|c|c|}
\hline \multicolumn{7}{|c|}{ Soil temperature at a depth of $20 \mathrm{sm}$ (mean), ${ }^{\circ} \mathrm{C}$} \\
\hline & 2014 Yr & $2015 \mathrm{Yr}$ & $2016 \mathrm{Yr}$ & $2017 \mathrm{Yr}$ & $2018 \mathrm{Yr}$ & 2019 Yr \\
\hline \multicolumn{7}{|c|}{ Orchard Floor Management Systems (OFMS) } \\
\hline Living Mulch (LM) & 23.5 & 22.1 & 23.4 & 23.3 & 26.8 & 21.1 \\
\hline Mechanical Cultivation (MC) & 25.9 & 23.6 & 24.8 & 24.3 & 27.7 & 23.0 \\
\hline Significance & $*$ & $*$ & $*$ & $*$ & * & * \\
\hline Significance $(\mathrm{Yr} \times \mathrm{OFMS})$ & * & NS & NS & * & * & $*$ \\
\hline \multicolumn{7}{|c|}{ Soil water content at a depth of $20 \mathrm{~cm}$ (mean), \% } \\
\hline Mechanical Cultivation (MC) & 13.9 & 16.4 & 14.7 & 23.9 & 16.0 & 25.7 \\
\hline Significance & $*$ & $*$ & $*$ & $*$ & * & $*$ \\
\hline Significance (Yr×OFMS) & $*$ & NS & $*$ & $*$ & $*$ & $*$ \\
\hline
\end{tabular}

$*$ denote $\mathrm{P} \leq 0.05$, or nonsignificantly different (NS).

Effects of floor management systems on soil conditions were significant during all 6 years of research. Year $\times$ orchard floor management systems interactions for soil temperature was significant in 2014 and in 2017-2019 years. Reductions in soil temperature under the LM treatment averaged $1.5^{\circ} \mathrm{C}$ (ranged from 0.9 to $2.4^{\circ} \mathrm{C}$ ) as compared to the $\mathrm{MC}$ treatment. The live mulch probably acted as an insulator - the presence of LM on the soil surface insulates the soil from the air temperatures. Lower soil temperature under LM has mostly been attributed to the reduced solar energy reaching the soil during hot period. Similar effects have been described in the scientific literature: the soil temperature in the surface $0-20 \mathrm{~cm}$ layer under live grass clover mulching treatment in the citrus garden was lower than control treatment without any cover; the soil water content was higher under live grass clover mulching treatment [27].

Living mulch increased soil water content, in comparison to MC (1.8 to $4.9 \%)$. Similar effects have been described by Simões [22]: the effects of natural vegetation mowing with those of tillage on soil water content and resistance to penetration was compared over an 8-year period, in a Mediterranean rainfed olive orchard. Soil water was higher in natural vegetation mowing, particularly in mid-summer and after the first autumn rains ( 1 to $2 \%$ ). Living mulch of the cover crop in apple orchards enhanced the soil water content by approximately $28 \%$, compared with conventional approach, where no cover crop was planted and natural weeds were controlled every month [28]. In the conventional system 
(tillage, no recycling of pruning material) the occurrence soil crusting and of compacted layers along the profile hindered infiltration and percolation of rainfall water influencing the soil water content below the $100 \mathrm{~cm}$ layer. The sustainable system (no-tillage, spontaneous vegetation cover, annual recycling of pruning material) was able to better store water from rainfall, received during the autumn-winter period, especially in the deepest soil layer (from 100 to $200 \mathrm{~cm}$ ). Water amounts stored by sustainable system were 45 and $17 \%$ higher than those retained by the conventional system [29].

This effects probably entirely due to increased organic matter and activity of soil biota by living mulch. The positive impact of live mulch on soil micro-ecology and soil quality has been confirmed by many studies $[6,28,30]$.

Year $\times$ OFMS interactions for soil water content was significant throughout all years of research, with the exception of 2015. Anomalous drought in August 2015 (as can be seen from tables 1 and 2) was likely to cause this deviation (precipitation was 98\% less than the annual average). Probably under such extreme conditions, the soil water content is more influenced not by the weather conditions, but by other factors. The drawback of our research is the lack of data on soil biological activity that could explain the trends identified.

Our studies have shown that the difference in trunk cross sectional area was insignificant both between OFMS and between cultivars in 2014 year, as can be seen from table 4 . However, starting from 2015, a significantly larger TCSA should be noted for MC, and in the following years the difference between OFMS increased (from 1.2 to 2.1 times).
Similar results have been reported in many scientific sources: live mulch adversely affects the growth processes of fruit trees through competition for water and nutrients [5].

The difference in TCSA between cultivars became significant, starting in 2016, when the TCSA for 'Valery Chkalov' was larger than $1.6 \mathrm{~cm}^{2}$ to 'Dilemma'. But, starting from 2017, 'Dilemma' exceeded 'Valery Chkalov' by this indic (from 4.6 to $2.3 \mathrm{sm}^{2}$ ). Year $\times$ OFMS interactions for TCSA was significant throughout all years of research, with the exception of 2017. Year $\times$ cultivar interactions for TCSA was nonsignificantly throughout all years of research. It should be noted that the studied cultivars are similar in phenological characteristics.

The shoot growth efficiency of cherry trees in 2014 did not differ significantly under the conditions of LM compared to MC (Table 5). But, starting from 2015, this indic began to grow under the conditions of LM, and was significantly higher compared to MC from 2015 to 2019 - 1.5, 2.6, 2.9, 2.6, 2.3 times, respectively.

A significant difference between the studied cultivars by the shoot growth efficiency was observed in 2014: this indic was significantly larger for 'Valery Chkalov' - 1.5 times, compared to 'Dilema'. But in 2016, SGE was significantly higher for 'Dilema' - 1.4 times, compared to 'Valery Chkalov'. In 2015, 2017-2019 there was no significant difference between the studied cultivars by SGE.

Throughout all the years of research, we have observed an increase in total leaf area under the conditions of LM compared to MC. Accordingly, leaf efficiency was larger 1.3-2.5 times (Table 6).

Table 4. Effects of year $\times$ OFMS and year $\times$ cultivar interactions on trunk cross sectional area for 'Valery Chkalov' and 'Dilema'sweet cherry.

\begin{tabular}{|c|c|c|c|c|c|c|}
\hline \multicolumn{7}{|c|}{ Trunk cross sectional area $\left(\mathrm{sm}^{2}\right)$} \\
\hline & 2014 Yr & $2015 \mathrm{Yr}$ & $2016 \mathrm{Yr}$ & $2017 \mathrm{Yr}$ & $2018 \mathrm{Yr}$ & 2019 Yr \\
\hline \multicolumn{7}{|c|}{ Orchard Floor Management Systems (OFMS) } \\
\hline Living Mulch (LM) & 3.1 & 5.5 & 8.7 & 15.8 & 19.5 & 25.1 \\
\hline Mechanical Cultivation (MC) & 3.1 & 6.7 & 13.8 & 23.9 & 37.1 & 52.2 \\
\hline Significance & NS & $*$ & $*$ & $*$ & * & * \\
\hline Significance $(\mathrm{Yr} \times \mathrm{OFMS})$ & $*$ & $*$ & $*$ & NS & $*$ & * \\
\hline \multicolumn{7}{|l|}{ Cultivar (CV) } \\
\hline Dilema & 3.0 & 6.0 & 10.5 & 21.8 & 30.1 & 39.8 \\
\hline Significance & NS & NS & $*$ & $*$ & $*$ & NS \\
\hline Significance $(\mathrm{Yr} \times \mathrm{CV})$ & NS & NS & NS & NS & NS & NS \\
\hline
\end{tabular}

* denote $\mathrm{P} \leq 0.05$, or nonsignificantly different (NS).

Table 5. Shoot growth efficiency for 'Valery Chkalov' and 'Dilema'sweet cherry.

\begin{tabular}{|c|c|c|c|c|c|c|}
\hline \multicolumn{7}{|c|}{ Shoot growth efficiency $=$ ratio of total annual vegetative growth to the trunk cross sectional area $\left(\mathrm{m}^{2} \mathrm{sm}^{-2}\right)$} \\
\hline & $2014 \mathrm{Yr}$ & $2015 \mathrm{Yr}$ & $2016 \mathrm{Yr}$ & $2017 \mathrm{Yr}$ & $2018 \mathrm{Yr}$ & 2019 Yr \\
\hline \multicolumn{7}{|c|}{ Orchard Floor Management Systems (OFMS) } \\
\hline Living Mulch (LM) & 1.3 & 4.7 & 8.0 & 8.5 & 6.1 & 2.7 \\
\hline Significance & NS & $*$ & $*$ & $*$ & $*$ & $*$ \\
\hline Significance $(\mathrm{Yr} \times$ OFMS $)$ & $*$ & $*$ & $*$ & $*$ & $*$ & $*$ \\
\hline \multicolumn{7}{|l|}{ Cultivar (CV) } \\
\hline Dilema & 1.6 & 4.2 & 6.4 & 5.3 & 4.1 & 2.0 \\
\hline Significance & $*$ & NS & $*$ & NS & NS & NS \\
\hline Significance $(\mathrm{Yr} \times \mathrm{CV})$ & NS & NS & $*$ & $*$ & NS & NS \\
\hline
\end{tabular}

* denote $\mathrm{P} \leq 0.05$, or nonsignificantly different (NS). 
Table 6. Leaf efficiency for 'Valery Chkalov' and 'Dilema'sweet cherry.

\begin{tabular}{|c|c|c|c|c|c|c|}
\hline \multicolumn{7}{|c|}{ Leaf efficiency $=$ ratio of total leaf area to the trunk cross sectional area $\left(\mathrm{m}^{2} \times \mathrm{sm}^{-2}\right)$} \\
\hline & 2014 Yr & 2015 Yr & 2016 Yr & 2017 Yr & 2018 Yr & 2019 Yr \\
\hline \multicolumn{7}{|c|}{ Orchard Floor Management Systems (OFMS) } \\
\hline Living Mulch (LM) & 0.8 & 2.4 & 3.7 & 3.1 & 3.3 & 2.7 \\
\hline Mechanical Cultivation (MC) & 1.4 & 1.8 & 1.8 & 1.4 & 1.6 & 1.1 \\
\hline Significance & $*$ & $*$ & $*$ & $*$ & $*$ & $*$ \\
\hline Significance $(\mathrm{Yr} \times \mathrm{OFMS})$ & $*$ & $*$ & $*$ & $*$ & $*$ & $*$ \\
\hline \multicolumn{7}{|l|}{ Cultivar (CV) } \\
\hline Dilema & 1.0 & 2.1 & 3.1 & 2.3 & 2.3 & 2.0 \\
\hline Significance & $*$ & NS & $*$ & NS & NS & NS \\
\hline Significance $(\mathrm{Yr} \times \mathrm{CV})$ & NS & NS & * & NS & NS & NS \\
\hline
\end{tabular}

* denote $\mathrm{P} \leq 0.05$, or nonsignificantly different (NS).

Weather conditions significantly influenced the shoot growth and formation of leaf surface: year $\times$ OFMS interactions for SGE and LE was significantly throughout all years of research.

The tendency to increase SGE and LE under the conditions of LM, compared with MC, shows that trees gradually overcome competition with natural herbs. As previously reported, according to the results of many years of research [31]: trees are overcoming competition with herbs in five to ten years. Here we show for the first time how sweet cherry trees overcome competition with herbs in the conditions of the Southern Steppe of Ukraine.

As can be seen from table 3, LM stores moisture in the soil. Based on the reduction of the cross-sectional area of the sweet cherry trees (Table 4), it could be concluded that the LM uses the stored moisture only on its own, and the trees suffer from drought. Instead, in our study the annual growth and leaf area under the conditions of LM are increasing (as can be seen from tables 5 and 6). That is, in this case, we have a more complex interaction of natural grasses and trees than competition. Annual growth can be influenced by both environmental factors (soil moisture content, temperature) and internal factors - the composition and activity of enzymes, hormones. We can assume that the reason here is the activity of soil microorganisms that exist in the rhizosphere of trees and natural herbs, first of all, plant growth promoting rhizobacteria and mycorrhizal fungi that can supply trees with moisture, nutrients, hormones, enzymes [8]. This may be the cause of the increase the annual growth and leaf area under the conditions of living mulch (compared with standard mechanical cultivation).

It is also possible that cherry trees of studied cultivars on the drought-tolerant rootstock are well adapted to the drought and under the conditions of LM form an alternative hydraulic architecture compared to the conditions of the MC. New growth and branches at the distal end of a plant maintain a constant flow rate and velocity of water [32]. It is shown that drought-resistant species can increase shoot growth and leaf area under drought conditions [33,34].

It should be noted that research in horticulture should continue for many years, our research will be continued, and the final conclusions will be obtained in 5-10 years. Future research should focus on the impact living mulch have at soil microorganisms and productivity of sweet cherry trees.

\section{Conclusions}

Our study demonstrated substantial impacts of floor management systems on soil conditions: living mulch reduced soil temperature in the surface $0-20 \mathrm{~cm}$ layer on averaged $1.5^{\circ} \mathrm{C}$ and increased soil water content on 1.8 to $4.9 \%$, compared with standard mechanical cultivation.

Under conditions of living mulch trunk cross sectional area of cherry trees significantly decreased - by 1.2-2.1 times, compared with standard mechanical cultivation.

Dynamics of shoot growth and leaf surface area depended on weather conditions, but the general tendency of increase of shoot growth efficiency and leaf efficiency under conditions of living mulch is observed - by 1.5-2.9 and 1.3-2.5 times, compared with standard mechanical cultivation.

Year $\times$ OFMS interactions for trunk cross sectional area, shoot growth efficiency and leaf efficiency was significantly throughout all years of research.

Investigated sweet cherry cultivars (Valery Chkalov and Dilemma) respondend to the floor management systems in a similar way - their biometric indices did not differ significantly.

\section{References}

[1] Fidalski, J., C. A. Tormena and A. P. Da Silva (2010). Least limiting water range and physical quality of soil under groundcover management systems in citrus. Sci. agric. $\begin{array}{llll}\text { (Piracicaba, } & \text { Braz.) } & 67 & \text { (4). }\end{array}$ 10.1590/S0103-90162010000400012.

[2] Tahir, I. I. and S. E. Svensson (2015). Floor Management Systems in an Organic Apple Orchard Affect Fruit Quality and Storage Life. HortSci. 50 (3): 434-441. DOI: 10.21273/HORTSCI.50.3.434.

[3] Gomez, J. A., M. Amato, G. Celano and G. C. Koubouris (2008). Organic olive orchards on sloping land: more than a specialty niche production system? J Environ Sci. 89 (2): 99109. DOI: $10.1016 /$ j.jenvman.2007.04.025.

[4] Duran, Z. V. H., M. J. R. Francia, P. C. R. Rodriguez, R. A. Martinez and R. B. Carceles (2009). Soil conservation measures in rainfed olive orchards in south-eastern Spain: impacts of plant strips on soil water dynamics. Pedosphere 19 (4): 453-464. DOI: 10.1016/S1002-0160(09)60138-7. 
[5] Atucha, A., I. A. Merwin, M. G. Brown et al. (2013). Soil erosion, runoff and nutrient losses in an avocado (Persea americana Mill) hillside orchard under different groundcover management systems. Plant Soil 368 (1-2): 393-406. DOI: 10.1007/s11104-012-1520-0.

[6] Yao, S. R., I. A. Mervin, G. W. Bird, G. S. Abawi and J. E. Thies (2005). Orchard floor management practices that maintain vegetative or biomass groundcover stimulate soil microbial activity and alter soil microbial community composition. Plant Soil. 271 (1/2): 377-389. DOI: 10.1007/s11104-004-3610-0.

[7] Nikiema, P., P. Nzokou, D. E. Rothstein and M. Ngouajio (2012). Soil microbial biomass as affected by groundcover management in a Fraser fir (Abies fraseri [Pursh] Poir) plantation after 1 year. Biol Fertil Soils. 48: 727. DOI: 10.1007/s00374-012-0666-5.

[8] Turrini, A., G. Caruso, L. Avio et al. (2017). Protective green cover enhances soil respiration and native mycorrhizal potential compared with soil tillage in a high-density olive orchard in a long term study. Appl Soil Ecol. 116: 70-78. DOI: 10.1016/j.apsoil.2017.04.001.

[9] Li Y., F. Pan and H. Yao (2019). Response of symbiotic and asymbiotic nitrogen-fixing microorganisms to nitrogen fertilizer application. $J$ Soils Sediments 19: 1948-1958. DOI: $10.1007 / \mathrm{s} 11368-018-2192-\mathrm{z}$

[10] Jie C., S. Weijun, X. Han, L. Yide and L. Tushou (2019). The Composition of Nitrogen-Fixing Microorganisms Correlates With Soil Nitrogen Content During Reforestation: A Comparison Between Legume and Non-legume Plantations. Frontiers in Microbiology 10: 508. DOI: 10.3389/fmicb.2019.00508.

[11] Mahmud K., S. Makaju, R. Ibrahim and A. Missaoui (2020). Current Progress in Nitrogen Fixing Plants and Microbiome Research. Plants. 9 (1): 97. DOI: 10.3390/plants9010097.

[12] Kalayu G. (2019). Phosphate solubilizing microorganisms: promising approach as biofertilizers. Int J Agron 10: 1-7. DOI: $10.1155 / 2019 / 4917256$.

[13] Wang Y., P. Li, B. Zhang et al. (2020). Identification of Phosphate-solubilizing Microorganisms and Determination of Their Phosphate-solubilizing Activity and Growth-promoting Capability. BioResources, 15 (2), 2560-2578. URL: https://ojs.cnr.ncsu.edu/index.php/BioRes/article/view/BioRes _15_2_2560_Wang_Identification_Phosphate_Solubilizing_M icroorganisms.

[14] Shandhu, H. S., S. D. Wratten, R. Cullen and B. Case (2008). The future of farming: the value of ecosystem services in conventional and organic arable land. An experimental approach. Ecol Econ. 64 (4): 835-848. DOI: 10.1016/j.ecolecon.2007.05.007.

[15] Christmann, S., A. Aw-Hassan, T. Rajabov, A. S. Khamraev and A. Tsivelikas (2017). Farming with alternative pollinators increases yields and incomes of cucumber and sour cherry. Agron. Sustain. Dev. 37: 24. DOI: 10.1007/s13593-017-0433-y.

[16] Balmer, O., L. Pfiffner, J. Schied et al. (2013). Noncrop flowering plants restore top-down herbivore control in agricultural fields. Ecology and Evolution 3 (8): 26-34. DOI: 10.1002/ece3.658.

[17] Belz, E., M. Kölliker and O. Balmer (2013). Olfactory attractiveness of flowering plants to the parasitoid Microplitis mediator: potential implications for biological control. BioControl 58: 163-173. DOI: 10.1007/s10526-012-9472-0.

[18] Khan, R., A. S. Shawl and M. A. Tantry (2012). Determination and seasonal variation of chemical constituents of essential oil of Hyssopus officinalis growing in Kashmir valley as incorporated species of Western Himalaya. Chemistry of Natural Compounds. 48 (3): 502-505. DOI: 10.1007/s10600-012-0290-5.

[19] Sanchez, E. E., A. Giayetto, L. Cichon et al. (2007). Cover crops influence soil properties and tree performance in an organic apple (Malus domestica Borkh) orchard in northern Patagonia. Plant Soil 292 (1-2): 193-203. DOI: 10.1007/s11104-007-9215-7.

[20] Neilsen, G. H., T. Forge, D. Angers, D. Neilsen and E. Hogue (2014a). Suitable orchard floor management strategies in organic apple orchards that augment soil organic matter and maintain tree performance. Plant Soil 378: 325-335. DOI: 10.1007/s11104-014-2034-8.

[21] Neilsen, G. H., D. Neilsen, F. Kappel and T. Forge (2014b). Interaction of Irrigation and Soil Management on Sweet Cherry Productivity and Fruit Quality at Different Crop Loads that Simulate Those Occurring by Environmental Extremes. HortScience 49 (2): 215-220. DOI: 10.21273/HORTSCI.49.2.215.

[22] Simões, M. P., A. Belo, C. P. Cruz and A. C. Pinheiro (2014). Natural vegetation management to conserve biodiversity and soil water in olive orchards. Spanish J. Agric. Res. 12 (3): 633-643. DOI: 10.5424/sjar/2014123-5255.

[23] Stefanelli, D., R. J. Zoppolo, R. L. Perry and F. Weibel (2009). Organic Orchard Floor Management Systems for Apple Effect on Rootstock Performance in the Midwestern United States. HortScience 44 (2): 263-267. DOI: 10.21273/HORTSCI.44.2.263.

[24] Tsupenko, N. F. (1990). Meteorology Agronomist's Handbook. Kyiv: Urozhay (in Ukrainian).

[25] Kulbida, M. I. and M. B. Barabash (2009). Climate of Ukraine: in the past and in the future. Kyiv: Steel (in Ukrainian).

[26] Kondratenko, P. V. and M. O. Bublik (1996). Methodology of field experimentswith fruit crops. Kyiv: Agrarian Science (in Ukrainian).

[27] Gu, C., Y. Liu, I. Mohamed et al. (2016). Dynamic Changes of Soil Surface Organic Carbon under Different Mulching Practices in Citrus Orchards on Sloping Land. PLOS ONE 11 (12): e0168384. DOI: 10.1371/journal.pone.0168384.

[28] Zheng, W., Q. Gong, Z. Zhao et al. (2018). Changes in the soil bacterial community structure and enzyme activities after intercrop mulch with cover crop for eight years in an orchard. Eur J Soil Biol 86: 34-41. DOI: 10.1016/j.ejsobi.2018.01.009.

[29] Palese, A. M. (2014). Influence of soil management on soil physical characteristics and water storage in a mature rainfed olive orchard. Soil Tillage Res. 144: 96-109. DOI: 10.1016/j.still.2014.07.010.

[30] Culumber, C. M., J. R. Reeve, B. L. Black, C. V. Ransom and D. G. Alston (2019). Organic orchard floor management impact on soil quality indicators: nutrient fluxes, microbial biomass and activity. Nutr Cycl Agroecosyst 115: 101. DOI: 10.1007/s10705-019-10007-2. 
[31] Atucha, A., I. A. Merwin and M. G. Brown (2011). Long-term effects of four groundcover management systems in an apple orchard. HortSci. 46 (8): 1176-1183. DOI: 10.21273/HORTSCI.46.8.1176.

[32] McCulloh, K. A. and J. S. Sperry (2005). Patterns in hydraulic architecture and their implications for transport efficiency. Tree Physiology 25 (3): 257-267. DOI: 10.1093/treephys/25.3.257.

[33] Kozlowski, T. T. and S. G. Pallardy (2002). Acclimation and adaptive responses of woody plants to environmental stresses. Bot. Rev 68: $270 . \quad$ DOI: 10.1663/0006-8101(2002)068[0270:AAAROW]2.0.CO;2.

[34] Mencuccini, M. (2003). The ecological significance of long-distance water transport: short-term regulation, long-term acclimation and the hydraulic costs of stature across plant life forms. Plant, Cell and Environment 26: 163-182. DOI: 10.1046/j.1365-3040.2003.00991.x. 